\title{
Sexual health of women prisoners in Peru: it is an issue of interest to public health?
}

\begin{abstract}
Objectives: The female inmate population is the fastest-growing worldwide. Despite this, they continue to be an invisible minority, ignoring their special sexual health needs. Thus, it is imperative to know the status of sexual health of women prisoners in Lima, given that this is a relevant problem for public health. The objective of this investigation is to identify the status of the sexual health of women inmates in prisons in Lima, Peru.
\end{abstract}

Materials and methods: The study was quantitative study with descriptive and crosssectional design. We applied a questionnaire developed for the study to 741 inmates of Lima and determined the frequency of the variables of interest with SPPS program.

Results: We found that 51.8 percent of women replied that they do not have annual Pap test and $78.5 \%$ referred that they did not performed the annual breast examination either. $42.4 \%$ noted that they have had vaginal infection in recent months, and $41 \%$ said that treatment for these was not provided. Just $2.7 \%$ say that were provided with pads for their menstruation period.

Conclusions: There are omissions in the care of the sexual health of prisoners which violates their right to complete health. The same quality of health services offered to free women is not offered to women prisoners, which can be interpreted as discrimination.

Keywords: sexual health, prisoner, sexually transmitted diseases, human rights, public health
Volume 7 Issue 2 - 2018

\author{
Ysis Judith Roa Meggo, Naysha Yamilet \\ Becerra Chauca \\ Universidad de San Martín de Porres, Perú
}

Correspondence: Ysis Judith Roa Meggo, Universidad de San Martin de Porres, Av. Salaverry I I36, Jr. Julián Sandoval I48, Dpto. 102. Urb Barrio Médico, Surquillo, Lima, Perú,Tel (05I) 940295985

Email yroam@usmp.pe,ysis.roa@gmail.com

Received: April 02, 2018| Published: April 09, 2018

\section{Introduction}

The world female prison population in 2006 was 660,000 women, representing close to $6.5 \%$ of the total world prison population. This particular population has increased 40\%, from 2000 to $2013 .{ }^{1}$ In Perú, female prison population was, in $2015,4,396 .{ }^{2}$ Despite the increasing amount of female incarceration, women prisoner still represent an invisible minority in relation to male prison population which is more than $90 \%$ of total Peruvian prison population. This is a major factor because it could cause their different needs to be ignored and omitted, prioritizing the needs of the majority, men. It is said that jails were designed for men prisoners; women were just put in there and treated by the same policies that were designed also for men. ${ }^{3-5}$ Unlike men, women are incarcerated, mostly for minor felonies like theft, prostitution, drug offenses; crimes that are related to lack of money to pay the bills, to maintain their drug addiction and to buy food (most of these women are the only ones who take care of their children). ${ }^{6,7}$ This means that their situation is much different from men's. Furthermore, they come from marginalized and poor sector and carry histories of physical and sexual abuse, neglect, violence, sex jobs and drug addiction; ${ }^{6}$ and the majority of them had limited access to health services, which increased their risk to get any disease, especially related to sexual and reproductive health, including gynecological cancer. ${ }^{7}$ Special attention should be paid to the unique and different women's situations and health, because they are clearly different from men. ${ }^{8}$

Sexual health is a state of physical, emotional, mental and social welfare related to sexuality issues, ${ }^{7}$ it is not just the absence of disease, dysfunction or illness. It requires a positive and respectful approach to be able to guarantee safe and gratifying sexual experiences free of coercion, discrimination and violence. The marginalized and poor scenario where female inmates come from, causes a decline of their sexual health, and also made hygiene be one of the most neglected risk factors. We must consider that hygiene has an important role in women sexual health due to the location of female urogenital system near to anal region, which facilitates the entry of microorganism from digestive system causing vaginal infections and pelvic inflammatory disease. ${ }^{9}$ If women are incarcerated with this diseases, or acquires them within their incarceration period and they are not properly treated, these diseases can become chronic and cause infertility, or worse, death. ${ }^{10}$ So, it is necessary to give gender health attention to these women, because this problem not only involves female prisoner, it also involves general population, free women. Releasing poorly health cared women who carry these communicable diseases, increases the risk of spread them among general population; in this way, it becomes a public health problem. ${ }^{11}$

To the European Committee for the Prevention of Torture and Inhuman or Degrading Treatment or Punishment, it is very important to offer access to health services and basic hygiene, the committee points out that not satisfying these requirements can be considered as a degrading treatment. ${ }^{12}$ Studies indicate that in female prisons, there are deficient health services and the conditions in which these inmates live, like overpopulation, violence and lack of water and electricity, ${ }^{11}$ increase the risk of spread of diseases. Furthermore, their personal basic hygiene is neglected, they are not provided with sanitary napkins for their menstrual periods, nor they are given a private space for personal cleanliness. ${ }^{7}$ To take care and maintain a high-quality 
sexual health, it is essential to respect and protect sexual rights. There are international guidelines that protect women prisoners' sexual and reproductive health, women who have lost their right to freedom of movement, but not their right to basic hygiene and health care which they must receive at the same level of quality as a free person. ${ }^{13,14}$ According to Peruvian Penal Code, the inmate has the right to reach, maintain and recover their physical and mental welfare, and the prison administration must provide what is "necessary to develop actions of prevention, promotion and recovery of health"; this code mentions that in female correctional facilities or in female sections of mixed prisons, there must be a special place provided with obstetrics and nursing's material resources, but it does not specify how to do it, nor presents any protocols. ${ }^{15}$ Given the growth of female prison population in Peru, and the resulting increase of the risk of sexual diseases' spread inside and outside prison, it is imperative to know the condition of female Peruvian inmates' sexual health and to analyze the execution of Standard Minimum Rules for the Treatment of Prisoners, in order to have a starting point that will generate improvements that will enhance living conditions of female inmates.

\section{Objective}

It was to identify the condition of Peruvian inmates' sexual health in correctional facilities of Lima Perú.

\section{Subjects and methods}

This is a quantitative study with a descriptive and transversal design. The population was composed of female inmates from 4 correctional facilities (Establecimiento Penitenciario E.P.) in Lima Perú: E.P. Mujeres de Chorrillos, E.P. Anexo de Mujeres de Chorrillos, E.P. Virgen de Fátima y E.P. Modelo Ancón II. We work with a universe of 1848 women and obtained a sample of 741 women. The questionaries' were applied to female inmates who previously signed the informed consent, during September and December 2013, inside the correctional facilities. It should be noted that the research protocol was reviewed and approved by the Institutional Ethics Committee for Scientific Research of Midwifery and Nursing Faculty of Universidad de San Martìn de Porres. The variables analyzed included, inmate's medical history, professionals that provide the health care, inmate's medical history related to sexual health and personal hygiene aspects. Data obtained was processed in the SPSS program and the results were presented in tables exposing frequencies.

\section{Results}

According to the inmates' age of the first sexual encounter, the range vary from 4 to 32 years old. The highest percentages (74\%) was the range from 14 to 18 years old. It was observed that $10.6 \%$ of women indicated their first sexual encounter was forced. In relation to their sexual activity, $12.5 \%$ of women indicated that they were currently having sexual intercourse with their partner. About the kind of protection they were using to prevent sexual transmitted diseases, from women who indicated that they were currently having sexual intercourse, $28.6 \%$ reveled they do no use any protection, $33.8 \%$ used condoms, $22.4 \%$ said they used hormone injections and $15.8 \%$ used contraceptive pills. Further, almost $50 \%$ pointed out that this protection is not delivered by the prison administration (Table 1).

Regarding health care, $91.4 \%$ of inmates indicated that when they have a medical problem, they are cared for inside the prison, only $4.3 \%$ of them are cared for outside of it. Women, $70.9 \%$ of them, revealed that when having a sexual and reproductive health problem, it was a female professionals who treated them; moreover $45.1 \%$ indicated that the professional was a midwife; $28 \%$, a physician; $8.6 \%$ a nurse, and $12.1 \%$ did not know what kind of professional treated them; and regarding inmates health care expectations, $89.9 \%$ stated that they preferred to be seen by a female professional. Furthermore, with respect to sexual health prevention, $51.8 \%$ said that they do not have annual Papanicolaou test and $78.5 \%$ said that did not have annual breast exam either (Table 2), (Table 3). According to their sexual health, $42.4 \%$ of women indicated that have had vaginal infections in the latest months, and $41 \%$ of them said that treatment was not provided to them. In relation to hygiene services provided at the facility, $83.8 \%$ of women revealed that there was enough water for maintaining themselves clean; in the other hand, $97.3 \%$ referred that the prison administration did not provide them with sanitary napkins for their menstrual period (Table 4).

Table I Characteristics of past and current female inmates' sexual activity in Lima Perú

\begin{tabular}{lll}
\hline Sexual activity's Characteristics & N & $\%$ \\
\hline Age of first sexual encounter & & \\
4-II years & II & $1.60 \%$ \\
I2-18 years & 574 & $81 \%$ \\
I9-25 years & 115 & $16.30 \%$ \\
26-32 years & 8 & $1.10 \%$ \\
Type of first sexual encounter & & \\
Consensual & 623 & $88.40 \%$ \\
Forced & 74 & $10.60 \%$ \\
Having sexual intercourse currently & 83 & $12.50 \%$ \\
Used of protective method against STD & & \\
No & 22 & $26.50 \%$ \\
Yes & 61 & $73.50 \%$ \\
Type of method & & \\
Condoms & 26 & $33.80 \%$ \\
Contraceptive injection & 17 & $22.40 \%$ \\
Contraceptive pills & 12 & $15.80 \%$ \\
Rhythm method & 5 & $6.50 \%$ \\
Method Provided by prison administration & 34 & $55.70 \%$ \\
\hline & & \\
\hline
\end{tabular}

Table 2 Characteristics of health professional that care for women prisoner in correctional facilities in Lima Perú

\begin{tabular}{lcc}
\hline Characteristics of health professional & N & $\%$ \\
\hline Type of professional that currently examines female inmates \\
Female professional & 349 & $70.90 \%$ \\
Male professional & 101 & $20.50 \%$ \\
Female and male professional & 42 & $8.50 \%$ \\
Type of professional that is preferred to examine inmates \\
Female professional & 587 & $89.80 \%$ \\
Male professional & 51 & $7.80 \%$ \\
Female and male professional & 16 & $2.40 \%$ \\
\hline
\end{tabular}


Table 3 Frequency of Gynecological Medical exams provided to female inmates in correctional facilities in Lima Perú

\begin{tabular}{lll}
\hline Gynecological Medical exams & N & $\%$ \\
\hline Annual PAP Test & & \\
Yes & 326 & $48.20 \%$ \\
No & 350 & $51.80 \%$ \\
Annual Breast Exams & & \\
Yes & 141 & $21.50 \%$ \\
No & 516 & $78.50 \%$ \\
\hline
\end{tabular}

Table 4 Characteristics and components of female inmates' sexual health in correction facilities in Lima - Perú

\begin{tabular}{lll}
\hline Sexual health's Characteristics and Components & N & $\%$ \\
\hline Vaginal infections in the latest months & & \\
Yes & 273 & $42.40 \%$ \\
No & 371 & $57.60 \%$ \\
Treatment was provided for these infections & & \\
Yes & 158 & $59 \%$ \\
No & 110 & $41 \%$ \\
Enough water for personal hygiene & & \\
Yes & 562 & $83.30 \%$ \\
No & 109 & $16.20 \%$ \\
Sanitary napkins provided & 18 & $2.70 \%$ \\
Yes & 661 & $97.30 \%$ \\
No & & \\
\hline
\end{tabular}

\section{Discussion}

Sexual health is an important aspect of life, it is a human right and the government must protect it in any scenario. Health must be seen as a global issue because it involves not only physical aspects; it implies social, emotional, psychological and cultural aspects that are imperative to look after, in addition to the context from which these women come from. Women prisoners must enjoy the same quality of health care as their counterparts in freedom, so the government must guarantee this health care which will result in improving quality of life of the prisoner and will also prevent the spread of diseases inside and outsides of prisons. This study shows that $10.6 \%$ of women revealed that their first sexual encounter was forced, similar results were found in Chile. ${ }^{16}$ This confirms what different studies indicate, that female inmates carry histories of sexual abuse and violence, which is an important issue to take into account when planning a health care program for them. This exposes that they can develop not only physical diseases, but also mental ones; which implies that they shall be examined also by qualified health professional related to that matter. We found that $12.5 \%$ of women indicated that they were currently having sexual intercourse with their partner and that they generally use a condom (33.8\%) as a protection against sexual transmitted diseases (STD). However, we also found that $22.4 \%$ used contraceptive injection also as a protection against STD and $15.8 \%$ used contraceptive pills. These answers show that female inmates do not know the difference between protection against STD and protection against unplanned pregnancy. These results are similar to Pereira's ${ }^{17}$ in Brazil, where women pointed out that they did not use condoms, but contraceptive pills, and that they did not know pills didn't protect them from STD. Fageeh's ${ }^{18}$ results show that a little more to $50 \%$ of inmates thought that they knew how to protect themselves from STD; however $42.6 \%$ did not know how to use a condom correctly. In relation to the percentage of use of condoms, our findings were similar to Cavieres and Hagedorn's in Chile ${ }^{16}$ who found that $67 \%$ did not use condoms in their sexual encounter, and to Oliviera's et al. ${ }^{19}$ who found that $20 \%$ said they use it in every sexual encounter; on the other hand, Fageeh ${ }^{18}$ found that only $4.9 \%$ of women use them to prevent STD. Likewise, we must draw attention to the fact that $55.7 \%$ of women who are currently having sexual intercourse and using any sort of protection, indicated that this protection was provided by the prison administration. However, this does not completely follow recommendations from "WHO Guidelines on HIV infection and AIDS in prisons" , that states that condoms and contraceptives must be available during detention period an prior to probation period or releasing of inmates. Further, it indicates that access to them must be easy, discreet and free and that prisoners can acquire them in different places within the facilities without having to ask for them. ${ }^{20}$ From these results we can assume that these women are poorly educated in health related issues, which is a key to disease prevention, especially in high risk populations like them.

The professionals who treat sexual and reproductive health related problems of women prisoners are mostly females (70.9\%). Rule 10 of United Nations Rules for the Treatment of Women Prisoners ${ }^{14}$ states that "If a woman prisoner requests that she be examined or treated by a woman physician or nurse, a woman physician or nurse shall be made available, to the extent possible, except for situations requiring urgent medical intervention." As we can see, this rule is being followed, because only $20.5 \%$ of women are cared for by a male professional, when almost $90 \%$ indicated they preferred to be examined by a female professional. It is important to highlight that $45.1 \%$ reported being cared by a qualified sexual and reproductive health professional (midwife) and $86.4 \%$, by at least one health professional (physician, nurse or midwife). These results show that some rules from the Standard Minimum Rules for the Treatment of Prisoners ${ }^{21}$ and from the Bangkok Rules, ${ }^{14}$ related to health care, are being fulfilled. With respect to disease prevention within the correctional facility, $51.8 \%$ reported that they did not have an annual Papanicolaou test; similar results were obtained by Nijhawan et al. ${ }^{22}$ and by General Defensory of Argentina's Nation ${ }^{23}$ where $32.31 \%$ reported that they were never examined for a PAP test during their reclusion period. On the other hand, our result contrast with Cavieres et al. ${ }^{16}$ and Binswanger's et al. ${ }^{24}$ who found that $83 \%$ reported having had at least one PAP test while incarcerated. We also found that $78.5 \%$ referred that they did not have an annual breast exam either. A similar situation was presented the General Defensory of Argentina's Nation ${ }^{23}$ and Chile's study. ${ }^{16}$ This investigation refers to clinical breast exam; however, there are other studies that mentioned the mammograms exam as a variable, ${ }^{22,24}$ with also, disappointing conclusions. These results reflect neglect of health care within correctional facilities in Lima Perú, Not having Pap tests and breast exams increases the risk of getting cancer, but the problem becomes bigger when we take into account that the majority of these women are the only ones who take care of their families; further, when being released (if that happens) they will need special care which, most probably can't be afforded. The recommendations given by international rules and guidelines ${ }^{7,13,14,21}$ indicate that all 
new prisoners must go through a complete medical exam (mental and physical) and that a new medical file must be opened as soon as the prisoner enters the prison. Also, if needed, the inmate should initiate treatment immediately for free or be sent to a specialized health center for his or her recovery. These recommendations also point out that jail time should serve as a period to execute disease preventions actions. According to the Federal Bureau of Prisons ${ }^{25}$ all female inmates between the ages of 21 to 65 should take Papanicolaou test every 3 years, and for women between 30 to 65 years old, it is recommended the combinations of PAP test and PVH test. The mammograms shall be provided every two years to women over 40 years with high risk of developing breast cancer, and also to women between 50 and 74 years with moderate risk. The National Institute of Neoplastic Diseases of Perú ${ }^{26}$ recommends that Clinical breast exams to be provided to every inmate annually and according to the Clinical Practice Guidelines of Cervical Cancer of the EsSalud ${ }^{27}$ all women that have initiated their sexual life must get a PAP test every year.

This study found that $42.4 \%$ female inmates referred to having had vaginal infections in the latest months, which can be partially explained by the fact that a great amount of women said that they do not use condoms in their sexual encounters. Similar to Garaycohea's et al. ${ }^{28}$ in a Chorrillos prison, where $52.5 \%$ of women reported some kind of vaginal secretion; and also similar to López-Barbosa's et al. ${ }^{29}$ results in Colombia that showed a $28.2 \%$ prevalence for vaginal infections. Some authors determined the prevalence of certain bacteria that causes vaginal infections, like Sutcliffe et al. ${ }^{30}$ who found $8.5 \%$ of vaginal infection and similar results found Fageeh et al. ${ }^{18}$ studies. ${ }^{31}$ In addition to this, $41 \%$ of women reported that they did not receive treatment for those infections, which clearly disobey international guidelines and rules for female inmates' treatment that state that every women prisoner must have gynecological consultations on a regular basis, focusing on diagnosis and treatment of STDs. Moreover, it states that medical service of the facility must examine any woman who manifest illness and give them the necessary health care until the end of treatment, and all this shall be offered at the same level of quality given to free people. ${ }^{7,14,21}$ Again, inattention is what characterized this prison health care. According to hygiene aspects, $83.8 \%$ indicated that there was enough water to keep their private parts clean; however, $97.3 \%$ pointed out that the prison administration did not provided them with sanitary napkins during their menstrual period. This result is in contrast to Argentina's findings ${ }^{23}$ where only $26.46 \%$ reported not being provided with sanitary napkins. As stated by Standard Minimum Rules for the Treatment of Prisoners, ${ }^{21}$ prisoner shall be required to keep themselves clean, and in order to do so, they should be provided with enough water and personal hygiene items. It is crucial to pay attention to women prisoner during childbearing age and menopause period; therefore, the necessary items for menstrual period shall be easily available as well as the container for their proper disposal. ${ }^{7}$ By these results, we can infer that Peruvian correctional facilities do not provide high quality health care, nor of basic hygiene items; thereby this can be qualified, by the European Committee for the Prevention of Torture and Inhuman or Degrading Treatment or Punishment as degrading treatment. Not paying attention to women prisoners' especial heath need is prejudicial; these women, when incarcerated, are under the care of the government, who must ensure, according to the penal code, their social rehabilitation, for that to happen, they must be in good health physically and mentally. Not having basic hygiene items involves not only physical but also mental consequences. Limitation of the study might be no information taken about anal intercourse that could be a choice for some women to avoid pregnancy with more risk of genital and renal infections. ${ }^{32}$

\section{Conclusion}

The present study shows positive and negative aspects related to the attention to the special health needs of prisoner women within Peruvian correctional facilities. Most of prison women had their first sexual encounter in an early age (14 to 18 years old) and a small portion of them stated that it was forced, which supports other investigations findings that reveal that female inmates carry with a history of abuse where their sexual health is neglected; not only in a physical way, but also in a cultural an educational way. A positive aspect is that women who get medical care within the facility, are examined mostly by a qualified professional. In this way, it is fulfilled what international rules stated about who shall examine the inmates. However, a negative aspect is the low quality of health care provided to these women. There is a low amount of women who have gotten a Papanicolaou test and even lesser amount of women with breast exam within the correctional facility, which increases the risk of getting cervical and breast cancer. Added to all this, there is neglect in providing treatment to women with vaginal infection which causes negative consequences to prisoners' sexual and reproductive life. Hence, this shows neglect, indifference and lack of empathy towards women prisoners' health by the prison administration.

Almost a third part of the female inmate populations that have sexual intercourse currently, uses condoms, it is a low percentage but it is even more interesting to discover that they do not recognize the difference between contraceptive methods and STD prevention methods. The free and easy distribution of condoms has not been observed in these facilities. Another issue is women's hygiene. It is a positive thing to identify that there is enough water to keep their private parts clean; however, the distribution of sanitary napkins is unfortunately much reduced. We must keep in mind that incarceration only suppresses the right of freedom; nevertheless, the condition in which these inmates live, violates their right to health because they are not provided with the same quality of health care as the free population, and this can be seen as discrimination.

\section{Acknowledgments}

We thank San Martín de Porres University for the funding provided to this investigation, and to National Penitentiary Institute (Instituto Nacional Penitenciario - INPE) for allowing the researches to access the correctional facilities for data recollection.

\section{Conflict of interest}

There is no conflict of interest between the Universidad de San Martín de Porres and the Instituto Nacional Penitenciario that were involved in the process of the investigation.

\section{References}

1. Penal Reform International Head Office. Global Trends Prison. $1^{\text {st }}$ ed. London: Penal Reform International Head Office; 2015.

2. Instituto Nacional Penitenciario. Informe Estadístico Penitenciario. Ministerio de Justicia y Derechos Humanos; 2015.

3. Currie B. Women in Prison: A Forgotten Population? Internet Journal of Criminology. Revista. 2012. 
4. Covington S. Women in Prison: Approaches in the Treatment of Our Most Invisible Population. Women and Therapy Journal. 1998;21(1):141-155.

5. Faiia M. Women Behind Bars. Rivier Academic Journal. 2009;5(2):1-6.

6. Girschick L. The Importance of Using a Gendered Analysis to Understand Women in Prison. Journal of the Oklahoma Criminal Justice Research Consortium. 1997/1998;4.

7. World Health Organization. Women's health in prison: Correcting gender inequity in prison health Copenhagen: WHO Regional Office for Europe; 2009.

8. Policy Brief: Women in Prison: Health and Mental Health. The Gender Health \& Justice Research Unit. 2012:1-8.

9. Cueva A, Cuauhtemoc C, Hernandez I, et al. Resultados de una encuesta epidemiológica de hábitos de higiene íntima en mujeres latinoamericanas. Rev Obstet Ginecol Venez. 2011;71(1):21-27.

10. Covington S. Women and the Criminal Justice System: Women's Health Issues. Jacobs Institute of Women's Health . 2007;17(4):180 182.

11. World Health Organization. Declaration of Prison Health as part of Public Health. $1^{\text {st }}$ ed. Moscow. World Health Organization; 2003.

12. Oficina de Naciones Unidas contra droga y delito. Manual de Instrucciones para la evaluación de la justicia penal. $1^{\text {st }} \mathrm{ed}$. Vienna: Publicación de las Naciones Unidas; 2010.

13. Conferencia de Ministros de Justicia de los Países Iberoamericanos. San José de Costa Rica; 18 - 19 de setiembre de 2008. Secretaría General CONJIB: 2008.

14. United Nations Office on Drugs and Crime. Directrices para el tratamiento de mujeres condenadas a penas privativas de la libertad, no privativas de la libertad y medidas para mujeres delincuentes. In Commission on Crime Prevention and Criminal Justice; 2009.

15. Código de Ejecución Penal del Perú. Art. 76 - 81, 2 de Agosto de 199.1

16. Cavieres M, Hagedorn F. Conocimientos y prácticas en salud sexual y reproductiva de Las mujeres que se encuentran recluidas en el recinto penitenciario de Valdivia durante el mes de mayo del año 2009. Valdivia: Universidad Austral de Chile. 2010;1-87.

17. Pereira C, Fonseca C, Esmeraldo M, et al. Knowledge of Female Prisoners in a City of Ceará, Brazil, about Sexually Transmitted Diseases. Open Journal of Nursing. 2014;4:630-636.

18. Fageeh WH. Sexual behavior and knowledge of human immunodeficiency virus/aids and sexually transmitted infections among women inmates of Briman Prison, Jeddah, Saudi Arabia. BMC Infect Dis. 2014;14:290.
19. Oliveira A, Gomes S, Amorin P, et al. Conhecimento, atitude e prática do uso de preservativos por presidiárias: prevenção das DST/HIV no cenário prisional. Rev Esc Enferm USP. 2012;46(3):711-9.

20. World Health Organization, UNODC, UNAIDS. Effectiveness of Interventions to Manage HIV in Prisons - Provision of condoms and other measures to decrease sexual transmission. Geneva: World Health Organization; 2007.

21. Bastick M, Townhead L. Women in prison A commentary on the UN Standard Minimum Rules for the Treatment of Prisoners. Geneva: Quaker United Nations Office; 2008.

22. Nijhawan AE, Salloway R, Nunn AS, et al. Preventive Healthcare for Underserved Women: Results of a Prison Survey. $J$ Womens Health (Larchmt). 2010;19(1):17-22.

23. Defensoría General de la Nación Argentina, et al. Women in Prison in Argentina: Causes, Conditions, and Consequences. $1^{\circ}$ ed. Chicago. the Avon Foundation for Women and the University of Chicago Law School; 2013.

24. Binswanger IA, White MC, Pérez-Stable EJ, et al. Cancer Screening Among Jail Inmates: Frequency, Knowledge, and Willingness. Am J Public Health. 2005;95(10):1781-1787.

25. Federal Bureau of Prisons. Preventive Health Care: Clinical Practice Guidelines. Washington. Federal Bureau of Prisons. 2013.

26. Instituto Nacional de Enfermedades Neoplásicas. Norma Técnica Oncológica para la prevención, detección, y manejo de lesiones pre-malignas del Cuello uterino a nivel nacional. $1^{\text {st }}$ ed. Lima. Instituto Nacional de Enfermedades Neoplásicas; 2008.

27. Seguro Social del Perú. Guía De Práctica Clínica De Cáncer De Cuello Uterino. Gerencia Central de Prestaciones de Salud; 2011.

28. Garaycochea M, Pino R, Chavez I, et al. Infecciones De Transmisión Sexual En Mujeres De Un Establecimiento Penitenciario De Lima, Perú. Revista Peruana de Medicina Experimental. 2013;30(3):423-7.

29. López-Barbosa N, Castro A, Gamboa E. Prevalencia y determinantes de las infecciones vaginales en las mujeres recluidas en una cárcel colombiana. Revista Chilena de Ginecología y Obstetricia. 2009;74(2):77-82.

30. Sutcliffe S, Newman SB, Hardick A. Prevalence and Correlates of Trichomonas vaginalis Infection Among Female US Federal Prison Inmates. Sex Transm Dis. 2010;37(9):585-590.

31. Fageeh W, Badawood S, Thagafi H, et al. Chlamydia trachomatis infection among female inmates at Briman prison in Saudi Arabia. BMC Public Health. 2014,14:267.

32. Hegazy A. Repetitive Anal Intercourse as a Potential Risk for Renal Failure. Acad Anat Int. 2015;1(1):1-2. 